The Review of Politics 79 (2017), 757.

(C) University of Notre Dame

doi:10.1017/S0034670517000675

\title{
CORRIGENDUM
}

\section{Richard Rorty's Unfulfilled Humanism and the Public/Private Divide-CORRIGENDUM}

\section{Giuseppe Ballacci}

doi:10.1017/S0034670517000249

The Review of Politics 79.3, 427-450, published online by Cambridge University Press on 4 July 2017.

The article by Giuseppe Ballacci, "Richard Rorty's Unfulfilled Humanism and the Public/Private Divide," published in The Review of Politics 79.3 (Summer: 2017): p. 438, footnote 56 misnamed the author of "On the Encyclopaedic Structure of the New Science." The article was written written by Andrea Battistini, not Alessandro Battistini.

The author apologizes for the error. 